\title{
The Translation of Nordic Workplace Democracy to the United States'
}

I Hege Eggen Børve ${ }^{2}$

Ass. Professor, Nord University, Levanger, Norway

\section{Elin Kvande}

Professor, Department of Sociology and Political Science, Norwegian University of Science and Technology (NTNU), Trondheim, Norway

\begin{abstract}
This paper explores a translation process of Nordic workplace democracy by using an empirical case study of a Norwegian company setting up a subsidiary company in the US. The paper contributes to existing accounts of how ideas and practices in international companies are translated from one institutional context to another by focusing on the role of agency in translation processes. Drawing on advances in Scandinavian institutional theory, the findings show how employees from the source context acted as skilled translators in the new local context and helped to close the skills-gap between employees with and without experience of workplace democracy. In addition, the US managers had work experience from the company in Norway as well as from the US. The employees' and managers' complementary contextual knowledge represented important institutional bridging skills in the process of reproducing workplace democracy in the new local setting. However, during the translation process, some of the elements in the workplace democracy model were discussed and modified. This demonstrates how the organizations' approach can change over time, from a reproducing to a modifying mode.
\end{abstract}

\section{KEYWORDS}

Institutional bridging skills / internationalization / translation processes / translation skills / translation strategy / translation theory / translators / workplace democracy

\section{Introduction}

- he focus of this article is on the translation of practices between two different institutional contexts. A substantial part of the internationalization in work life takes place through the expansion of international companies (Connell et al. 2005), where ideas and practices are translated to a new setting. Translation research has contributed important insight as to how management concepts travel across time and space and the process of adoption and adaption to fit new contexts (Czarniawska \& Sevón 1996). A lot of attention has been paid to how concepts are modified in a new local context (Røvik 2014; Wæraas \& Sataøen 2014). Translation processes of practices such as lean management (Andersen \& Røvik 2015), diversity management (Boxenbaum 2006), IT management (Doorewaard \& Bijsterveld 2001), HRM practices (Pudelko \&

\footnotetext{
${ }^{1}$ You can find this text and its DOI at https://tidsskrift.dk/njwls/index.

${ }^{2}$ Corresponding author: Hege Eggen Børve, E-mail: Hege.E.Borve@nord.no.
} 
Harzing 2007), reputation management (Wæraas \& Sataøen 2014), and trade union ideas (Cassell \& Lee 2016) may be subject to diverse modifications from practices in the source contexts and lead to local organizational variations. For instance, studies of how European companies, e.g., German-based multinational companies located elsewhere in Europe, have shown that they tended to leave their own models of work practices behind and instead have developed practices in line with the traditions in Anglophone countries (e.g., Bluhm 2001; Dörrenbächer 2004). This is understood as a consequence of institutional impacts affecting organizational practices in the new context.

A tradition in the translation field emphasizes diverse agents' practices and the negotiation of ideas in the local context. Agents such as policy makers, consultants experts, and social networks involved in translation processes, are studied in relation to decision-making processes, how they apply various strategies (Czarniawska \& Sevón 1996, Kirkpatrick et al. 2013; Røvik 2016; Wedlin \& Sahlin 2017) such as editing rules (Sahlin-Andersson 1996) and translation rules (Røvik 2016), framing (Boxenbaum 2006), tensions and congruences between agents' orientations (Grinsven et al. 2020) and the skills needed in these processes (Røvik 2016). These studies suggest 'ongoing adaptation and adjustment' (Weick \& Quinn 1999, p. 362). Recently, there has been a call for more attention to the local context and for further research on the role of agency in translation processes such as how translators do translation work (Outila et al. 2020), their experiences, interpretations, and decisions (Huising 2016; Mueller \& Whittle 2011). With some exceptions (Røvik \& Andersen 2015), we know little about internal employees as translators in the translation process (Wæraas $\&$ Sataøen 2014), and indeed, the involvement of employees in the translation of the Nordic workplace democracy to a new context seems to be less prevalent than one might expect.

The aim of this paper is to build on and contribute to Scandinavian institutional theory by providing insight into how an organization's translation process in international companies takes place and how actors involved anchor their practices in the local context. Through a study of a translation process of workplace democracy from an architecture company located in Norway to a new office in the US, we ask how the organization approached the translation process and how the employees' perceptions and practices of workplace democracy are embedded in the local institutional context. In this paper, Nordic workplace democracy refers to various ways of involving employees in how the company is organized and managed. Workplace democracy is one important feature of the Nordic work model (Børve \& Kvande 2018). When analyzing how the organization approached the translation process in a different institutional context, the paper pays special attention to the actors involved, asking who the translators are, what they do, and what translation skills are needed in the translation process. This perspective includes an understanding of actors in different institutional contexts translating ideas differently and thereby constructing different versions of the translated ideas. In doing this, we address the recent call within translation studies for further micro-level research on the role of internal agency in translation processes (Outila et al. 2020). We start by presenting the literature of Scandinavian institutional perspective on translation studies and describing the theoretical perspective and methods used in this study. In order to explore the translation process, the empirical results are presented in two parts, first by analyzing the organization's translation strategies, and second by analyzing local actors' perceptions and practices of workplace democracy. 


\section{Translation theory as a theoretical framework}

Within Scandinavian institutional theory, institutions are understood as social constructs, in which cultural and cognitive dimensions are important. Institutions are viewed as open systems that are strongly influenced by socially constructed value systems (Lundberg \& Sataøen 2014). Translation refers to the transformation of institutional models and practices from one setting to another by emphasizing the contextualization of the transformation processes (Czarniawska \& Joerges 1996). In this tradition it is common to consider translation as a complex continuous, evolving process of change (Cassell \& Lee 2017), in adapting, adjusting, and interpreting ideas and practices to fit local needs and circumstances (Pipan \& Czarniawska 2010). Ideas and models are expected to be stripped of time- and space-bound features before beginning their travel in the translation process (Wæraas \& Nielsen 2016). This involves the processes of disembedding (Czarniawska \& Joerges 1996) or de-contextualizing (Røvik 2007) and materializing the idea into an intermediary. De-contextualization from one institutional setting to another is an attempt to make the idea more abstract than the original practice and thus more transferable in the new context (Røvik ibid.). Re-embedding and contextualization comprise the process by which an idea is travelling through time and space and introduced into a new context (Czarniawska \& Joerges 1996).

Translation strategies are assumed to be applied when an idea or practice is transferred from one context to another. This does not, however, mean that there are written instructions, only that certain rules have been followed (Sahlin-Andersson 1996). Empirical studies on the adoption and implementation of ideas understand either organizations' absorptive capacity as top-down strategies or down-up implementation strategies being decisive for variations in outcome (Røvik 2017). Wæraas and Sataøen (2014) used a linguistics-inspired approach to analyze translation rules when Norwegian hospitals adopted new management ideas. They found that during the process the hospitals used three different translation rules: copying, omission, and addition. Røvik (2007) defines these translation rules in the following way. Copying is the most basic translation rule and implies a deliberate replication strategy leading to a reproduced mode or outcome. Addition entails making the idea more explicit and concrete by adding information that is not presented in the original model or is unclear, leading to a modified outcome. Omission is the opposite of addition, in the sense that it leaves out or tones down some of the components of the original model. Alteration refers to the more radical modification of an idea, signifying that the outcome is seen as a local innovation (Røvik 2007).

Actors in the local context may translate ideas differently because they have different interests, interpretations and reactions to them (Nicolini 2010). This process involves negotiations where meanings, interpretation, and interests change and gain ground (Wæraas \& Nielsen 2016). Some actors may accept them, add, modify, or let ideas drop as well as being modified by them (Boxenbaum 2006). An important aspect is that the actors who convey ideas across different contexts have translating skills that are related to de-contextualization and contextualization (Andersen \& Røvik 2016). The term translation skills refer to knowledge about how to translate practices and ideas between organizational contexts in order to achieve the desired ends (Røvik 2016:2). This includes factual knowledge of the topic, which is being translated, a profound knowledge of the different cultural contexts and knowledge about how a certain 
concept has been practiced in other organizations. Translation also requires linguistic skills (Czarniawska-Joerges \& Joerges 1990) because words and concepts have different meanings in different settings. It is also important to be aware of the history and norms of the organizational context where the ideal is to be appropriated (Wœraas et al. 2011). De-contextualization requires knowledge of the prerequisites needed for a practice to function in a particular context, while contextualization requires knowledge about how to introduce and translate ideas and practices (Røvik 2007). Workplace democracy in the Norwegian context is the idea behind the practices to be discussed in this article, which is elaborated in the next section.

\section{Workplace democracy and institutional contexts}

Workplace democracy is often considered synonymous with terms such as co-determination, industrial democracy, self-management, co-management, work control, humanization of the workplace, formal participation, and the quality of working life (Nightingale \& Clarkson 1982). Generally, workplace democracy refers to ideas about how labor-management works and how successful co-operation or employee involvement (Egels-Zandén \& Hyllman 2007) proves to be. Included here are practices such as voting, discussions, and deliberative and participatory decision-making (Pausch 2014). One important aspect is that employees have control over goal-setting and strategic planning and can influence organizational decisions (Foley \& Polonyi 2006).

Nordic workplace democracy (Børve \& Kvande 2018) is understood in terms of rights, practices and procedures, which are conceptualized by referring to direct and indirect participation in the work process. Direct participation refers to self-managing workgroups, the redesign of jobs, and other work-related matters where employees either individually or in teams make decisions about their own organization of work (Knudsen et al.2011). Indirect participation refers to representative participation, where workplace democracy can be achieved through individual membership in trade unions and/or membership in other representative bodies, such as work councils or joint consultative committees, that provide a voice on issues that are important in the workplace or enterprise. The combination of strong trade unions and regulated working conditions are designed to protect and empower employees (NOU 2021).

A consequence that is often emphasized is the high degree of trust between managers, union representatives, and employees, which has a positive impact on both corporate democracy and productivity (Hernes 2006). Nordic countries often have a management model that embraces values and norms of equality, solidarity, and democracy (Grenness 2003). These values are reflected in the fact that work organizations often have few hierarchical levels and are characterized by a short distance between managers and workers.

In contrast to the Nordic context, the US has a liberal work model that is characterized by a deregulated labor market with very few regulations for the involvement and participation of employees in decision-making at the organizational level (Walby 2009). Nine of 10 U.S. workers have no right to collectively negotiate, which is a rate far lower than in any other similar democracy (BLS 2021). There are, however, some differences between public and private sector. Collective bargaining contracts are more common in the public sector than in the private sector; $30 \%$ in contrast to $7 \%$. Most of this is 
due to nearly universal coverage in a few states. Overall, the US has had a significant reduction in the rate of union membership, both in private and public sector. Although labor unions have declined, unions still provide a voice for millions of workers in shaping their wages, benefits, and working conditions (Denice \& Rosenfeld 2018; Western $\&$ Rosenfeld 2011). In recent years, a growing number of worker advocacy groups are experimenting with new approaches to organizing and representing workers outside of the traditional labor law framework (Andrias 2020).

\section{Method and design}

This case study was carried out to address the question of how the workplace democracy model was translated to a new institutional context. The local translation process took place in an architecture and interior design company, Snøhetta, during its establishment of an office in the US. The decision to set up a subsidiary in the US was made when the company won the tender to design the Ground Zero memorial museum pavilion in New York. The background for selecting Snøhetta's process of translation was reportage in the media about its success as a company with Norwegian working conditions operating in New York. This study took place in 2011, which was 6 years after the office in the US was set up. The purpose of our case study was to gain insights into the translation process of the Nordic workplace democracy model to a new context.

When selecting the criteria for choosing informants, it was important to have people from the founding group who could provide information about the first phase in the process. We also made sure to include people who had joined the organization at a later stage. Employees who were parents were included to get information on how working conditions affected family life. Data were collected by means of 19 individual interviews with employees and managers at the company's offices in Oslo (seven interviews) and New York (12 interviews). Three of the informants were part of the management team. At the US office, most of the informants (eight) were from the US, while a minority (four) were originally from Europe. Six women and six men were interviewed. All the managers at the US office, three informants, had previously lived and worked at the Norwegian office. The majority at the US office had work experience from other architecture firms in the US and/or other countries. The informants from the US office except one worked full-time. During the interview period the office in the US had 34 employees, all of whom were architects.

The interview questions covered themes such as work organization, conditions at work, work processes, working time, work-family issues, forms of cooperation, management, and their involvement in the translation process. Informants were asked explicit questions about experiences with Norwegian work traditions and the undertaking to translate the 'Oslo model', as it was called at the New York office. The informants were also asked to talk about how workplace democracy was practiced, and if there had been any changes since the start up. An interview guide was used to ensure that all the informants were interviewed about the same topics. Each interview lasted approximately 90 minutes and was recorded and later transcribed. Fourteen of the interviews were conducted in English, while five were conducted in Norwegian and translated into English. 
The analysis of the interviews took place in two main stages. In the first step, informants with no experience of the US office were excluded from the analysis (five people). In the second, analytical step, the transcriptions were coded as belonging to thematic categories, such as workplace democracy, their role in the translation process, experiences, and practices. In order to explore the translation process, we first analyzed how the organization discussed the translation process and the strategies they used, followed by analyzing which actors the organization involved in the local organizational context. In the second part, we analyzed the translation process by emphasizing employees' perceptions and practices of direct- and indirect participation. In the material skills were analyzed in relation to knowledge, attitudes, and understandings needed in the work process and decision making. An important issue in this part was to explore whether any practices of the original Norwegian democratic ideas had changed during the translation process.

\section{The organization's translation strategies}

\section{De-hierarchization as the main organizational principle}

During the establishment of the office in the US, the staff consisted of 10 people. Six people, two managers and four employees, were transferred from Norway to the office in the US. This implied that they had experiences with workplace democracy from the office in Norway. The rest, four employees, were locally hired. Thus, the majority (six people) had experience with Norwegian labor practices during setting up phase, whereas four employees had no experiences with either the Norwegian work context or workplace democracy practices. Both managers had knowledge about traditions in the US working life such as how organizations are organized and labor practices. During the start up in the US, there were numerous discussions about what should be transferred from the Norwegian context to the US context. One of the managers said:

When we started up the US office, there was a big discussion, and in fact it was decided that everything here must be identical to the way it was in Norway. [...] The idea was to create an office that was a clone of the office in Norway. The goal was not to just copy it, however, but to transform what 'is best about it'.

Discussion focused on the meaning of 'cloning'. While some thought this implied translating all the Norwegian office's ideas and practices, others expressed the view that some things needed to be adapted to the US context. An important part of this discussion related to what they did not want to include. One of the managers talked about this by referring to the office in Norway:

It was stated several times that we don't want a corporate US structure at all. We don't admire or even condone the way they operate. I feel exactly the same way. I don't like the corporate structure that you find here. So, for me, it was a relief to be able to say: "Ok, let's go and take things that we learned in Norway - which are gender balance and employee transparency - as much as possible, and see how they fit into the new work environment. 
In addition to creating a culture characterized by gender balance and employee transparency, the organization wanted to translate what was called a relatively flat organizational structure and team organization. In addition, this included constructing a salary ladder with few levels and small salary gaps between the top and the bottom.

It was considered to be difficult to create a complete copy of the Norwegian office, but based on their experience, they wanted to de-hierarchize the structure by cutting out the top level and introducing a team-based organization. This implied establishing an office that was different from the standard US work model. One of the managers explained how he thought architecture firms in the US were organized:

In most offices it's hierarchical; there is one person who directs everything, or three people. The way it normally works is that it is a pyramid. A person at the top [...], often a man. They are so busy that they cannot do the job, so they find two right-hand, superimportant, very smart people who get paid a lot of money to do the work that the one at the top can't do. Under those two people, they have their own 'slave' teams. I will call them slaves in that situation because they often work for free; literally, they have nothing to say.

The US work model was described as having a hierarchical structure that the organization wanted to change. The organizational structure was viewed as an important contextual condition in order to translate workplace democracy to the US context. They wanted to create employee transparency by cutting out the top level to have an open flow of information between colleagues. This included constructing the organization as a team-organization. This type of team organizational structure was described in the following words by one of the employees:

During the 16 years that I have been working here, there have been many ups and downs. We have succeeded, because Snøhetta has this incredible ability to design fantastic projects in a team, which resembles what we in Norway call "Dugnad" which again is an important part of the Nordic work model.

This employee considered team organization to be the 'essence' of the Snøhetta organization, which also, according to her, has been the road to success for the company. This statement resembles the ideas of workplace democracy - how labor-management, co-operation, and employee involvement work. In contrast to American practices, these principles are integrated in the Norwegian Work-Environment law and constitute an important element of the Nordic work model.

The organization introduced de-hierarchization as the main organizational principle at the US office. The manager explained that they had removed the top level and organized the employees in teams. He said: 'It is relatively flat', meaning that the company was organized as an organizational structure with few hierarchical levels and little distance between the managers and the employees. When interviewing the employees at the New York department, we asked them to draw an illustration of the organization structure according to how they experienced it. None of them made a drawing, which illustrated a pyramid. Instead, many of them made drawings of unclear circles with bubbles inside. This illustrates that the employees did not consider the organization as hierarchically structured. 


\section{Involving skilled translators in a collective translation process}

In the initial phase of the translation process, the organization wanted to ensure that most of the employees had experience and skills from the Norwegian office. The reason for this was explained by one of the employees:

They [the managers] wanted to have employees with experience from the office in Norway at the office in the US, especially in the initial phase. [...] It was an unexpressed idea that one had to bring along a bit of what is perceived as a kind of Snøhetta culture, which consisted of both Norwegian working conditions and maybe some special ideas about how Snøhetta worked on projects. So, it was a conscious effort.

The employees were expected to take part in the organization's translation process as opposed to being only project workers or consultants. They did not ask questions about or have any objections to their role in the translation process but rather took it for granted that they should bring along their practical skills and experiences of the original practices of workplace democracy. Involving employees as key actors and expecting them to promote the organizational values of workplace democracy in the new setting show that the organization considered them important and necessary experts in the translation of values and practices to the US office. This may indicate that they had opportunities to shape ideas strategically in accordance with their own interpretations and preferences.

The managers had contextual specific skills about the US working life traditions and knowledge about how the workplace democracy had been practices in the Norwegian context. This implied that they had knowledge of the prerequisites needed for workplace democracy to function in a particular context. The managers' skills thus complemented the employees' practical skills. Transferring employees and managers from one location to another suggests that complementary skills were considered important and demanded in the translation of Nordic workplace democratic. This indicates that the organization expected there to be a skills gap in the new context and the skills needed for constructing workplace democracy in the US department, because these employees' expertise had been developed in another country. Recognizing transferred managers and employees as experts and making them responsible in the translation process helped to close the skills gap. Engaging and using employees and managers in the new context also illustrate that a collective process was used as a strategy to ensure institutional bridging skills. An assumption is that this strategy was used to make it easier to resonate workplace democracy with local interests in the new context.

\section{Employees' perceptions and practices of work-place democracy in the local organization}

To explore the construction of workplace democracy in the local organization, we analyzed employees' perceptions and practices of direct and indirect participation at the time when the interviews took place. 


\section{Direct participation: promoting involvement and cooperation}

A team- organization with a decentralized decision-making process entails giving employees more influence and requires less management control. The employees noted that the assignments were organized into project teams. Employees could join several teams at the same time, depending on the size of the projects being worked on. When a new project started, the employees and the managers gathered around a large table in the communal area for brainstorming. Through joint discussions, ideas and suggestions were developed and sometimes rejected. These organizational principles promoted individual involvement and cooperation between the employees and between the employees and the managers.

The employees experienced these organizational principles as a collaborative form of work in which the whole team was involved. The US employees said that these principles were not what they were used to. One of them said, 'We do not work like this in the United States; it's more about the individual, and competition between the employees'. The US practice implied working on individual project ideas and then presenting the ideas to the other employees. The goal was to win the tender, which required having the best proposal. An important practice at Snøhetta, New York, involved asking questions such as 'What do you think?' instead of giving answers. The focus was on elaborating and developing ideas through open communication processes that were expressed in terms of 'It is not about criticizing, it is about questioning' and 'We have what I would call freedom of speech, which means that everyone can say anything and be listened to'. In addition to dialogue between the employees, the managers participated in the project discussions. Such cooperation was unusual, as one of the employees observed:

I have worked here for only six months, but I feel, from what I can see so far, that it is much more cooperative. If one of the owners has an opinion, it's not like: 'I'm the owner of the firm and at the end of the day we are going to make it like this.' Perhaps it is another way of thinking. They [managers] say: 'What about...?'.

The managers' involvement of employees had an important symbolic effect by downplaying the differences connected to positions in the hierarchy. Thus, the managers' work practices based on collective principles resembled the Scandinavian leadership model (Schramm-Nielsen et al. 2004). The break with strong hierarchical organizational forms and the introduction of decentralized decision-making affected the employees' work conditions. One of the employees who was hired shortly after his graduation as an architect in the US commented on these work conditions:

The opportunity to work on the project was one thing that was pretty great and unusual. But the opportunity to really participate at a very high level, you know, just coming out of graduate school, was also very unusual. [...]. The level of responsibilities you can have as a young and inexperienced person because it is less hierarchical is fantastic. [...]. I am more used to waiting to hear what someone, what my boss or my project manager has to say. Here, you try to get everyone on board and make sure that everyone is happy with those decisions. It is ok to say, 'what do you think' as opposed to just bringing a bunch of options to the table and saying, 'pick one', which is maybe what happens a lot in the US. 
This employees' story confirms that many of the democratic working conditions in the Norwegian office were translated to and contextualized in the US office. Working as a junior member, he was able to be part of a team, was given responsibilities, and was involved in decision-making. The work conditions were different from his expectations and previous experience.

The ideas were articulated as 'to adapt to the Scandinavian kind of egalitarian model', which some of the local employees found challenging. The 'openness of discussion and questioning' was new for them. One expressed that he was 'looking for a hierarchical model to fit into, the flow of power was confusing". Employees needed to be socialized into the organization and had to learn how to practise these ideas. An important part of learning was for employees to develop a sense of security 'so you can question openly without jeopardising your future salary negotiations, your job, or your career'. Direct participation signals that the organization considers the employees competent and trustworthy. All the employees expected, and were encouraged, to contribute their ideas as architects.

In order to maintain direct participation, it was important to recruit employees who supported these collective norms. However, as the project volume increased, they needed to increase the workforce by hiring more local employees, which then made it more difficult to implement these ideas. The first year was described by one of the employees as 'a beginning of something, it was a great and optimistic kind of struggle of ideals'. According to the employees with experience from Norway, it was challenging to integrate the workplace democracy to which they were accustomed to the US context. One of the Norwegian employees, talked about this phase: 'At the office in Oslo there is room to address difficult questions, whilst in New York it took a longer time to do this. We tried, though, and we worked a lot with that when I was in New York'. Another employee explained that this happened because of lack of knowledge and experience with a decentralized work organization and workplace democracy. He stated:

Americans are more steadfast as to where one is, how one does it, how one works. But they are more uncertain about working the way we do, in groups. [...] One does not necessarily have a boss who gives orders about the way it should be done and delivered.

An illustration of this is a story told during the interviews about a very talented employee who had previously worked in a prestigious architecture office in the US, which was described as having an 'aggressive and competitive' culture. Shortly after the colleague had started to work in the office, several employees went to the manager and said that the new colleague was 'challenging' and that they 'could not work with this person'. This employee did not get an extension at the end of his employment contract period. Orientation towards personal achievement was viewed as a practice that violated the norms of cooperation, which illustrates that these norms had been contextualized in the organization.

Another way of decentralizing responsibility was to involve the employees in the project processes with the customers, with all team members attending at least one customer meeting during a project period. If the teams consisted of more than six members, all the employees took it in turns to attend the customer meetings. Customer collaboration is a kind of direct participation in which the employees take part in decisions concerning the projects. From the employees' point of view, participation in customer 
meetings was interpreted as a sign that they were seen, included, and heard. Involvement in customer meetings was a new experience for the employees. One of the employees elaborated on this by saying:

When a project team is going to travel to another city, they make an effort to include the junior members as well. It is not just the project managers or team leader, but everyone from the team is included. That's something I have not experienced in any of the companies for which I worked previously. You must be on a special level, and then you are the one who attends all the meetings. I like how integrated it is, that all team members are important and need to be there to hear, think, and contribute.

Participating in customer meetings implied that the employees, regardless of whether they were project managers, project participants, junior members, or senior members, were involved in all phases of the project. This illustrates that neither hierarchical placement nor seniority was of importance. From the employees' point of view, it meant that everyone was included in the venues in which the decisions were made. Influencing the daily work required independent employees who were able to take responsibility for their own tasks without anyone giving them orders about what to do.

\section{Indirect participation - Elected representation and collective salary negotiations}

Workplace democracy through indirect participation or representative participation implies that elected representatives such as shop stewards, safety representatives, and work directors can exercise influence. The US office introduced representative participation regulated by collective agreements. The representative had the right and duty to do his or her best to create a good working environment. The employees had annual joint meetings where they discussed topics related to the workplace which were concluded by preparing reports to be delivered to the management. The employee representative had the right to attend board meetings and was entitled to comment on behalf of the employees but did not have voting rights. If the employees had questions and complaints that they wanted to submit to the management, they used the elected representative as their channel. The employees experienced that the management was responsive to their input and that they had a direct impact on their own workplace. One of the employees said: 'Most of the time, they are very open to what we propose and want to talk about, which is amazing; it's really cool that it actually happens, because it never happened anywhere else'. Here, 'anywhere else' referred to US offices in general.

The organization also introduced a collective bargaining system. The representative participated in the preparation and implementation of local wage negotiations and cooperated with the managers in the preparation of employment contracts and employee guidelines. This was considered quite novel according to one of the employees; 'this is another thing that is strange, because the employees get to determine many things, [...] how the salary structure works, vacation time, this office environment, is the air in here good?' Wage negotiations took place as joint decisions between the employee's representative and the employer. The practice that was used for salary negotiations was the same as that used for collective bargaining at the Oslo office. The fact that an employee 
representative had the right to participate in different channels for collective participation, such as wage negotiations and board meetings, showed that, although the employees were not unionized, representative co-determination in accordance with Norwegian cooperation traditions was formalized and institutionalized.

The wage ladder was short in the sense that there were only minor pay differences between the employees and between the employees and the managers. About the wage system, one of them said:

When I first started there was a salary ladder which was based on how many years you had worked and if you had any special degrees and accreditations. When you started, you were not able to negotiate a salary at all. It was based on qualifications, and you came in knowing that everyone else was on that same ladder. You could also see how much everyone else makes as well.

Employees' and managers' salary level were based on criteria that were well known to the staff. This was unusual, because individual performance assessments and bonus schemes were dominant wage-fixing practices in the US. Wage bargaining is an institution which, combined with a small wage ladder and wage transparency, contributes to a high degree of equality. This gave the employees an understanding of the organization's wage philosophy, strategies, and practices. In contrast to a collective bargaining system, individual negotiations were considered to be very stressful 'because you always have to talk to your bosses to get any sort of additional money'. Collective negotiation and wage pay transparent were considered easier to deal with and to have a positive impact on the work environment according to one of employees:

\footnotetext{
It operates in a very just and clearly defined way and so it is one less thing to worry about when you do your work, but it feels like there is more camaraderie or like more the group feels a bit strengthened, when everyone knows where they are situated. I don't know ... Sometimes it felt like when salaries are unknown there is a strange competitiveness and aggressiveness. I kind of feel like the salary ladder eliminated that. It is a really weird thing. I mean like a salary would be that big of an issue that it would really affect the way you corporate, but it is kind of true, it does.
}

The wage system was perceived as having a positive and equalizing effect on the collective feeling in the group and the team work, while a secret salary system enhanced a competitive atmosphere. Compared to other US architecture firms, employees perceived the wage levels as 'fair'. However, some wanted to change the collective and transparent salary practice. The discussion started because some of the employees said that, because they were not able to negotiate with people they wanted to hire, they lost them. Others expressed the view they were 'locked into these salary levels'.

The wage continued to be discussed in the organization, and at the time the interviews took place, the negotiations were still not settled, and the organization seemed to be in a kind of a limbo situation concerning this question. One of the employees expressed frustration about this: 'The wage system used to be very open but not any longer. Vacation time was also changed, and the salary system was changed so that is not transparent any longer'. At the time the interviews took place, there were heated discussions about this change. According to one of the employees there were only a 
few employees who supported a non-transparent wage system: 'I think for the most part, ninety-nine percent want it to be transparent and kind of back to the way it was. You knew exactly what everyone was making, but now it is anywhere from sixty to eighty hundred'. This illustrates that, even if the employees accepted and used the elected employee representative, there were discussions about the wage system. They also told a story about how the employees responded when the managers wanted to reduce the number of holiday weeks. One of the employees spoke about this:

When I started working here, we had five weeks of vacation. At one point it was reduced to three weeks. Then we complained. The staff clustered together as a group and said: 'We need more than this'. We got four weeks; so, we still have less than we started with, but more than they thought to give us.

When the management wanted to change the holiday arrangement, the employee representative organized a meeting for all the employees. Compared to typical US practice, they were allowed long holidays, and all the employees agreed that they did not want to reduce their holiday time. The negotiation between the representative and management ended in a compromise when the management reduced the holiday arrangement by one week less than they had originally suggested. The fact that the employees organized themselves and acted as a collective voice when management wanted to change the holiday arrangement illustrated that the employees had influence and that collective bargaining power was institutionalized. Both indirect and direct participation was anchored in the new context, while the meanings and interpretations of workplace democracy in the organization were still discussed and negotiated. Changing the wage system and reducing vacation time in accordance to traditions existing in the local setting show that some of the translated ideas were modified. In additional, this illustrates that employees had the opportunities to shape ideas strategically in accordance with their own interpretations and preferences. The ongoing discussion about these topics is also an illustration of how translation processes continue, and that the outcome might change over time.

\section{Concluding discussion}

The main contribution of this paper is to build on and strengthen existing accounts of how ideas and practices in international companies are translated from one institutional context to another. We address the recent call within translation studies for further research on the role of agency in translation processes by analyzing how translators do translation work (Outila et al. 2020), their experiences, interpretations, and decisions (Huising 2016). While there has been substantial research on translators such as policy makers, external experts, and social networks involved in translation processes and how they apply various strategies, we know little about internal employees as translators in the translation process. Focusing on how workplace democracy was translated from an architecture company located in Norway to a new department office in the US, the paper contributes to Scandinavian institutional theory by providing insight into how employees are used as skilled translators in a translation process. The study shows that knowledge about workplace democracy in the source context and knowledge about the receiving context are important for anchoring new practices in the receiving context. 
Accordingly, the organization's translation strategy was to transfer employees and managers from the office in Oslo to the new context in order to use them as translators. These employees and managers had complementary contextual knowledge about the Norwegian working life and workplace democracy, which included direct participation in the work process through teamwork and influencing decisions concerning their work organization. These employee's work experiences implied that they had skills in cooperation with both colleagues and managers in teams and taking part in collective decisionmaking. They also had experienced being empowered employees in a de-hierarchized organization structure at the Oslo office. Thus, they had acquired skills in practicing the workplace democracy that the organization wanted to translate. Transferring employees to the new location indicates that the organization considered the employees to possess translation skills, which were needed to close a skills gap between employees in the new context and the skills the organization needed for constructing workplace democracy because the US employees' work life experience had taken place in different institutional setting.

In addition, downplaying hierarchies was considered to be an important contextual condition in the translation process. Involving employees as translators means that they were empowered and given the opportunity to impact the construction of workplace democracy in the new context. This demonstrates a high degree of trust in the employees as well as embracing values of equality and democracy. It also demonstrates how a down-up implementation strategy (Røvik 2017) impacts the translation outcome. Using this translation strategy which included management collaborating with employees resembles how Nordic managers practices ideas of workplace democracy (SchrammNielsen et al. 2004; Westenholz 2011).

The analyses of the translation of direct participation to the new context show that employees collaborated in teams and influenced their daily work situation. These practices resemble labor rights in the Norwegian Working Environment Act. Indirect participation was institutionalized by the employees' right to elect an employee representative who could take part in different channels for collective participation. This practice is a parallel to how indirect participation is organized in the Norwegian cooperation model (Hernes 2006; NOU 2021). This happens despite the US's deregulated working life context and the lack of institutional arrangements such as laws, agreements, and traditions for participation and cooperation. Recognizing employees as skilled experts and using them as translators in the local context demonstrates a translation process were employees had the necessary institutional bridging skills, which led to reproducing workplace democracy in the new local context. According to Røvik (2007), copying is the most basic translation rule which leads to a reproduced mode. These findings contrast previous translation studies of workplace democracy, which show that organizations seldom transfer national work practices to new contexts (i.e., Bluhm 2001; Dörrenbächer 2004).

As the project volume increased in the US office, the organization needed to increase the workforce by hiring local employees. This made it more difficult to anchor workplace democracy in the local context because the new employees were critical to some of these practices. This led to changes in parts of the wage system, even if most of the employees supported workplace democracy and had internalized these practices in their daily work. However, when the managers wanted to change the holiday arrangement the employees organized themselves and acted as a collective voice. This illustrates that the collective bargaining power was institutionalized. Thus, the translation process was sensitive to how 
new employees were enrolled in these new practices. This demonstrates how the organizations' approach can change over time, from a reproducing to a modifying mode which means omitting some of the components of the original model (Røvik 2006). Actors in the local context may translate ideas differently because they have different interests, and reactions to them (Nicolini 2010). This process involves negotiations where meanings, interpretation, and interests change and gain ground (Wæraas \& Nielsen 2016). Some actors may accept them, add, modify, or let ideas drop as well as being modified by them (Boxenbaum 2006). As this micro-level case study demonstrates, new practices must resonate with local interests in order to be maintained. However, the sustainability of workplace democracy over the long-term is an open question because translation processes continue and represents an ongoing adaptation and adjustment (Weick \& Quinn 1999).

\section{References}

Andersen, H., \& Røvik, K. A. (2015). Lost in translation: a case-study of the travel of lean thinking in a hospital, BMC Health Services Research 15(401): 9. doi: https://doi. org/10.1186/s12913-015-1081-z.

Andrias, K. (2020). Union Rights for All: Towards Sectoral Bargaining in the United States, in R. Bales \& Garden, C. (Eds.), The Cambridge Handbook of U.S. Labor Law: Reviving American Labor for a 21st Century Economy, (pp. 56-63), Cambridge: Cambridge University Press. doi: https://doi.org/10.1017/9781108610070.

BLS (2021). New release. Union member 2020. Burau of Labor statistics. US department of labor. Available at: https://www.bls.gov/news.release/pdf/union2.pdf [Accessed 10 December 2021].

Bluhm, K. (2001). Exporting or Abandoning the "German-model"? Labour policies of Germany Manufacturing Firms in Central Europe, European Journal for Industrial Relations 7(2): 153-173. doi: https://doi.org/10.1177/095968010172004.

Boxenbaum, E. (2006). Lost in Translation: The Making of Danish Diversity Management, The American Behavioral Scientist 49(7): 939-948. doi: https://doi.org/10.1177/00027 64205285173.

Børve, H. E. \& Kvande, E. (2018). Den norske samarbeidsmodellen: egnet for eksport til USA? [The Norwegian cooperation model: suitable for export to the US?], Tidsskrift for samfunnsforskning 59(1): 26-40. doi: https://doi.org/10.18261/issn.1504-291x-2018-01-02.

Cassell, C., \& Lee, B. (2016). Understanding Translation Work: The evolving interpretation of a trade union idea, Organizational Studies 38(8): 1085-1106. doi: https://doi.org/ 10.1177/0170840616670435.

Connell, R. W., Wood, J. \& Crawford, J.(2005). The Global Connections of Intellectual Workers. An Australian Study, International Sociology 20(1): 5-26. doi: https:/doi.org/ $10.1177 / 0268580905049907$.

Czarniawska, B., \& Sevón, G. (1996)(Eds.). Translating organizational change, Berlin: De Gruyter. doi: https://doi.org/10.1515/9783110879735.

Czarniawska, B., \& Joerges, B. (1996). Travels of ideas: organizational change as translation, Göteborg: University-School of Economics and Commercial Law/Gothenburg Research Institute. doi: https://doi.org/10.1515/9783110879735.13.

Denice, P. \& Rosenfeld, J. (2018). Unions and Nonunion Pay in the United States, 19772015, Sociological Science 5: 541-561. doi: https://doi.org/10.15195/v5.a23.

Dörrenbächer, C. (2004). Fleeing or Exporting the German Model - The Internationalization of German Multinationals in the 1990s, Competition and Change 8(4): 443-456. doi: https://doi.org/10.1080/1024529042000304455. 
Doorewaard, H., \& Bijsterveld, M. V. (2001). The Osmosis of Ideas: An Analysis of the Integrated Approach to IT Management from a Translation Theory Perspective, Organization 8(1): 55-76. doi: https://doi.org/10.1177/135050840181004.

Foley, J., \& Polanyi, R. (2006). Workplace Democracy: Why Bother? Economic and Industrial Democracy 27(1): 173-191. doi: https://doi.org/10.1177/0143831x06060595.

Greenwood, R., Oliver, C., Sahlin, K., \& Suddaby, R. (2017). Introduction, in Greenwood, R., Oliver, C., Lawrence, T. B., \& Meyer, R. E. (Eds), The SAGE Handbook of Organizational Institutionalism, (pp. 1-46), (2nd ed.), Thousand Oaks, CA: Sage. doi: https://doi. org/10.4135/9781849200387.nl.

Grenness, T. (2011). The impact of national culture on CEO compensation and salary gaps between CEOs and manufacturing workers, Compensation and Benefits Review 43(2): 100-108. doi: https://doi.org/10.1177/0886368710393136.

Grenness, T. (2003). Scandinavian managers on Scandinavian management, International Journal of Values-Based Management 16(1): 9-21. doi: https://doi.org/10.1023/a:1021977 514976.

Grinsven, M, Sturdy, A. \& Heusinkveld, S. (2020). Identities in Translation: Management Concepts as Means and Outcomes if Identify Work, Organizations Studies 41(6): 873-897. doi: https://doi.org/10.1177/0170840619866490.

Gupta, A. K., \& Govindarajan, V. (2000). Knowledge flows within multinational corporation, Strategic Management 21(4): 473-496. doi: https://doi.org/10.1002/(sici)1097-0266 (200004)21:4<473::aid-smj84>3.0.co;2-i.

Husing, R. (2016). From adapting practices to inhabiting ideas: How manager restructure work across organizations, Research in the Sociology Organization 47: 383-413, Emerald Group Publishing Limited. doi: https://doi.org/10.1108/s0733-558x20160000047025.

Hernes, G. (2006). Den norske mikromodellen. Virksomhetsstyring, partssamarbeid og sosial kapital [The Norwegian micro-model. Corporate governance, partnership and social capital], Report 25, Oslo: Fafo.

Kirkpatrick, I., Bullinger, B., Lega, F., \& Dent, M. (2013). The translation of hospital management models in European Health systems: a framework for comparison, British Journal of Management 24: 48-61. doi: https://doi.org/10.1111/1467-8551.12030.

Knudsen, H., Busck, O., \& Lind, J. (2011). Work environment quality: the role of workplace participation and democracy, Work, Employment and Society 25(3): 379-396. doi: https://doi.org/10.1177/0950017011407966.

Long, E., \& Franklin, A. L. (2004). The paradox of implementing the government performance and results act: top-down direction for bottom-up implementation, Public Administration Review 64(3): 309-319. doi: https://doi.org/10.1111/j.1540-6210.2004.00375.x.

Mueller, F. \& Whittle, A. (2011). Translating management: A discursive devices analysis, Organization Studies 32: 187-210. doi: https://doi.org/10.1177/0170840610394308.

Nicolini. D. (2010). Medical Innovation as a Process of Translation: A Case from the Field of Telemedicine, British Journal of Management 21: 1011-1026. doi: https://oi.org/ 10.1111/j.1467-8551.2008.00627.x.

Nightingale, D. V. \& Clarkson, M. B. E. (1982). Workplace Democracy: An inquiry into Employee Participation in Canadian Work Organisations. In D. V. Nightingale (Ed.), Workplace in perspective, (pp. 173-194), University of Toronto Press. doi: https://doi.org/ 10.3138/9781442623422-012.

NOU (2021). Den norske modellen og fremtidens arbeidsliv. Utredning om tilknytningsformer og virksomhetsorganisering [The Norwegian model and the working life of the future. Study on forms of affiliation and business organization]. NOU 9, Oslo.

Pausch, M. (2014). Workplace Democracy: From a Democratic ideal to a Managerial Tool and Back, The Innovation Journal 19(1): 1-19. 
Pudelko, M. \& Harzing, A.-W. (2007). Country-of-origin, localization, or dominance effect? An empirical investigation of HRM practices in foreign subsidiaries, Human Resource Management 46(4): 535-559. doi: https://doi.org/10.1002/hrm.20181.

Outila,V., Piekkari, R., Mihailova, I. \& Angouri, J. (2020). “Trust But Verify”. How middle management use proverbs to translate an important management concept, Organization Studies 12-21. doi: https://doi.org/10.1177/0170840620934065.

Pipan, T., \& Czarniawska, B. (2010). How to construct an actor-network: Management accounting from idea to practice, Critical Perspectives on Accounting 21(3): 243-251. doi: https://doi.org/10.1016/j.cpa.2008.04.001.

Røvik, K.A. (2007). Trender og translasjoner [Trends and translations], Oslo: Universitetsforlaget.

Røvik, K. A. (2016). Knowledge Transfer as Translation: Review and Elements of an Instrumental Theory, International Journal of Management Reviews 18(3): 290-310. doi: https://doi.org/10.1111/ijmr.12097.

Sahlin-Andersson, K. (1996). Imitating by Editing Success: The construction of organizational fields and identities, in Czarniawska, B. \& Sevón, G. (Eds.), Translating organizational change, (pp. 69-92), Berlin, New York: De Gruyter. doi: https://doi. org/10.1515/9783110879735.69.

Schramm-Nielsen, J., Lawrence, P., \& Sivesind, K. H. (2004). Management in Scandinavia Culture Context and Change, Cheltenham: Edward Elgar Publishing. doi: https://doi. org/10.4337/9781845423575.

von Platen, S. (2015). The communication consultant: an important translator for communications management, Journal of Communication Management 19(2): 150-166. doi: https://doi 10.1108/JCOM-06-2013-0049.

Walby, S. (2009). Globalization and varieties of modernity, EURAMERICA 42(3): 391-417.

Wedlin, L. \& Sahlin, K. (2017). The imitation of management ideas. In Greenwood, R., Oliver, C., Lawrence, T. B, \& Meyer, R. E. (Eds.), The SAGE Handbook of Organizational Institutionalism. (pp. 102-127). (2nd ed.), Thousand Oaks, CA: Sage. doi: https://doi. org/10.4135/9781446280669.n5.

Weick, K. E. \& Quinn, R. E. (1999). Organizational change and development, Annual Review of Psychology 50(1): 361-86. doi: https://doi.org/10.1146/annurev.psych.50.1.361.

Western, B. \& Rosenfeld, J. (2011). Unions, Norms, and the Rise in U.S. Wage Inequality, American Sociological Review 76(4): 513-37. doi: https://doi.org/10.1177/0003122411 $\underline{414817}$.

Wæraas, A. \& Sataøen, H. L. (2014). Trapped in conformity? Translation reputation management into practice, Scandinavian Journal of Management 30(2): 242-253. doi: https:// doi.org/10.1016/j.scaman.2013.05.002. 